\title{
Effect of Heat-Treat Methods on the Soluble Calcium Levels in the Commercial Milk Products
}

\author{
Sung-Ho Yoo, Seung-Bum Kang, Jin-Ho Park, Kyung-Sang Lee, Jin-Man Kim¹, and Sung-Sik Yoon* \\ Division of Biological Science and Technology, Yonsei University, Wonju 220-710, Korea \\ ${ }^{1}$ Department of Food Science and Biotechnology of Animal Resources, Konkuk University, Seoul 143-701, Korea
}

\begin{abstract}
Milk is well known to be rich in some nutrients such as protein, calcium, phosphorus, and vitamins. In particular, absorption and bioavailability of calcium receive lots of attention because calcium is very little absorbed until it is changed to the ionized form in the intestine. In this study, concentration of the soluble calcium was determined in the commercial bovine milk products, which were processed by different heat-treatment methods for pasteurization. As for general constituents, lactose, fat, protein, and mineral were almost same in the liquid milk products by different processors. Ultrafiltration of the skimmed milk caused little change in the permeate as for lactose content but both fat and protein decreased. $\mathrm{pH}$ values ranges from 6.57-6.62 at room temperature and slightly increase after centrifugation, 10,000 g, $10 \mathrm{~min}$. Rennet-coagulation activity was the lowest in the ultra high temperature (UHT-)milk compared to the low temperature long time (LTLT-) and high temperature short time (HTST-)milk products. Each bovine milk products contains $1056.5-1111.3 \mathrm{mg} / \mathrm{kg}$ of Ca. The content of sulfhydryl group was the lowest in raw milk compared to the commercial products tested. For the skimmed milks after ultrafiltration with a membrane (Mw cut-off, $3 \mathrm{Kd}$ ), soluble Ca in the raw milk was highest at $450.2 \mathrm{mg} / \mathrm{kg}$, followed by LTLT-milk $336.4-345.1 \mathrm{mg} / \mathrm{kg}$, HTST-milk 305.5-313.3 mg/kg, UHT-milk 370.3-380.2 mg/kg in the decreasing order. After secondary ultrafiltration with a membrane (Mw cut-off, $1 \mathrm{kD}$ ), total calcium in raw milk had a highest of $444.2 \mathrm{mg} / \mathrm{kg}$, and those in the market milk products. As follow: UHT-milk, 371.3 to $378.2 \mathrm{mg} / \mathrm{kg}$; LTLT-milk, 333.3 to $342.2 \mathrm{mg} / \mathrm{kg}$; HTST-milk 301.9 to $311.2 \mathrm{mg} / \mathrm{kg}$ in a decreasing order.
\end{abstract}

Key words: bovine milk, heat-treat method, soluble calcium, sulfhydryl group, ultrafiltration (UF)

\section{Introduction}

As a natural food rich in nutrients such as protein, calcium, phosphorus and vitamins, milk has energy required for human activities and nutrients needed for building up the human body and metabolism (Chai, 1988). In particular, rich calcium content in milk prevents dietary fat from being absorbed and is dedicated to inhibit cholesterol absorption in collaboration with plant-origin phytosterols in the alimentary track. When the calcium intake from dietary source increases, it exerts to lower the serum cholesterol as well as fat level. However, when the calcium intake is insufficient, it adversely affects the bone growth and maintenance, resulting in osteoporosis or bone fracture and also vulnerability to various diseases such as high blood pressure and hypercholesterolemia (Kim, 1993; Lee

*Corresponding author: Sung-Sik Yoon, Division of Biological Science and Technology, Yonsei University, Wonju 220-710, Korea. Tel: 82-33-760-2251, Fax: 82-33-760-5576, E-mail: sungsik@yonsei.ac.kr et al. 1993; Lee and Kim, 2002; Park and Lee, 2002). Now that market milk contains about 1,000-1,200 mg of calcium per $\mathrm{kg}$, and cheese and yogurt provide more calcium than market milk, the fermented dairy products are of great significance as an effective dietary source of calcium.

Calcium present in milk is actually divided into two types of the colloidal calcium and the soluble calcium. According to the earlier reports, about two thirds of the calcium is colloidal and the rest is soluble form, taking up approximately 10 percent. The calcium phosphates found in milk is saturated in terms of the phosphates and mostly insoluble (Holt and Jenness, 1984; Neville et al. 1994).

The raw bovine milk usually contains pathogenic microorganisms and also active enzymes, which frequently hamper digestion and absorption of milk. Accordingly, it becomes a common process that the raw milk goes through the heat-treatment as a safety measure (Lee, 1999). Once the raw milk has been heat- treated, it is able to destroy the inherent microorganisms and extend the shelf life after production. There are three types of heat-treatment process of raw milk for sterilization purpose: the low tem- 
perature-long time (LTLT, $30 \mathrm{~min}$ at $65^{\circ} \mathrm{C}$ ), the high temperature-short time (HTST, $15 \mathrm{~s}$ at $72^{\circ} \mathrm{C}$ ), and the ultrahigh temperature (UHT, $2-4 \mathrm{~s}$ at $135^{\circ} \mathrm{C}$ ) methods (Woo and Maeng, 1998).

These pasteurization and sterilization processes affect in various ways on the sensory and nutritional quality of milk (In and Jung, 2001). Sandhu (1973) reported that the total calcium content in the heat-treated milk products was not changed, while Burton (1984) claimed that heating processes of milk influenced the balance of calcium salts in its distributions, resulting the reduced soluble calcium contents because the ionic calcium combined with the phosphates or the denatured proteins turns into the colloidal calcium form while the calcium moves to the inside of casein micelles, reduced the content of the ultrafiltrable calcium accordingly. Depending on the heattreatment processes, the soluble calcium and the ionic calcium are shifted into the casein micelles along with the structural changes of milk proteins, and consequently the total soluble calcium content decreases (Woo and Maeng, 1998). Pouliot et al. (1989) reported that soluble calcium reduced when raised the temperature up to $90^{\circ} \mathrm{C}$. There are several papers that the relative ratios between the ionic calcium and the soluble calcium content is changed by heat treatments, resulted that physicochemical properties of milk change. But it still remains uncertain about calcium distributions according to the heat-treatment methods applied to the processing milk.

Therefore, this study was performed in order to compare the soluble calcium content and physicochemical properties as a function of heat-treatment on the commercial liquid milk products produced by such methods as LTLT-, HTST- and UHT- methods currently adopted by the domestic milk processors.

\section{Materials and Methods}

\section{Commercial milk products used}

The liquid milk products used in this experiment were purchased at superstores and marketing agencies in Korea. Conditions for pasteurization of each product are listed in Table 1. Non-homogenized raw milk was supplied by Dairyzen Inc. (Wonju) and raw farm milk was transferred to this laboratory within an hour. To remove milk fat, the centrifugal separation (Supra 28K, Hanil, Korea) was conducted for $10 \mathrm{~min}$ at $10,000 \mathrm{rpm}$ before experiments.

\section{Ultrafiltration of skimmed milk}

Ultrafiltration of skimmed milk was conducted to mea-
Table 1. Heat-treatments methods on raw milk and some commercial bovine milk products

\begin{tabular}{cccc}
\hline \hline $\begin{array}{c}\text { Methods of } \\
\text { heat-treatment }\end{array}$ & Symbol ${ }^{*}$ & $\begin{array}{c}\text { Pasteurization/Sterilization } \\
\text { Temperature } \\
\left({ }^{\circ} \mathrm{C}\right)\end{array}$ & Time \\
\hline None (Raw milk) & $\mathrm{R}$ & - & - \\
\hline Low temperature & $\mathrm{A}$ & 63 & $30 \mathrm{~min}$ \\
long time (LTLT) & $\mathrm{B}$ & 63 & $30 \mathrm{~min}$ \\
\hline Hight temperature & $\mathrm{C}$ & 63 & $30 \mathrm{~min}$ \\
short time (HTST) & $\mathrm{D}$ & 72 & $15 \mathrm{~s}$ \\
Ultra high temperature & $\mathrm{F}$ & 72 & $15 \mathrm{~s}$ \\
(UHT) & $\mathrm{G}$ & 130 & $2 \mathrm{~s}$ \\
& $\mathrm{H}$ & 130 & $2 \mathrm{~s}$ \\
& & 130 & $2 \mathrm{~s}$ \\
\hline
\end{tabular}

*R: Raw milk, A: Ildongfoodis, B: Konkuk, C: Pasteur, D: Sangha, E: Denmark, F: Seoul milk, G: Maeil, H: Namyang

sure the content of the soluble calcium. The ultrafiltration module (Model 3622, Vision Scientific, Korea) mounted with a cellulose membrane was used and the ultrafiltration was carried to collect the permeates, which were subjected to analysis. As for ultrafiltration membranes (MA 01821, Millipore, USA), two kinds of membranes, high (Mw cut-off $30 \mathrm{kD}$ ) and low molecular (Mw cut-off 10 $\mathrm{kD}$ ), were used, depending on the molecular weight of proteins to be removed.

\section{Determination of crude protein content}

This was carried out according to the official AOAC method (1995) and the content of crude protein was calculated by the formula below with the use of the conversion factor (6.38).

$$
\begin{aligned}
& \text { Crude protein }(\%)=\frac{\left(V_{1}-V_{2}\right) \times F \times \text { Conversion Faxtor }}{E} \times 100 \\
& E= \text { sample volume }(\mathrm{mg}) \\
& F= \text { titre of } 0.1 \mathrm{~N} \mathrm{HCl} \\
& V_{1}= \text { Volume }(\mathrm{mL}) \text { of } 0.1 \mathrm{~N} \mathrm{HCl} \mathrm{consumed} \mathrm{for} \mathrm{the} \\
& \text { samples } \\
& V_{2}= \text { Volume }(\mathrm{mL}) \text { of } 0.1 \mathrm{~N} \mathrm{HCl} \mathrm{consumed} \mathrm{for} \mathrm{the} \\
& \text { blank test }
\end{aligned}
$$

\section{Determinantion of fat concentration}

Fat was determined using the Röse-Gottlieb method (AOAC, 1995).

\section{Determination of lactose concentration}

HPLC (Waters Alliance System 2690, USA) was used in the quantitative analysis of lactose as the operational conditions shown in Table 2. Each of $5 \mathrm{~mL}$ sample was taken and mixed well with $30 \mathrm{~mL}$ of deionized water to mess up to $50 \mathrm{~mL}$ with acetonitrile, and then centrifugated (J2- 
Table 2. Operating conditions of HPLC for lactose analysis in the commercial milk products

\begin{tabular}{ll}
\hline \hline \multicolumn{1}{c}{ Items } & \multicolumn{1}{c}{ Conditions } \\
\hline Instruments & Waters Alliance System 2690 (Waters, USA) \\
Column & Carbohydrate (Waters, USA) \\
Detector & RI \\
Flow rate & $1.4 \mathrm{~mL} / \mathrm{min}$ \\
Injection volume & $250 \mu \mathrm{g}$ \\
Mobile phase & Pure water 25\%, acetonitrile 75\% \\
\hline
\end{tabular}

$21 \mathrm{M} / \mathrm{E}$, Beckman, USA) at $10,000 \mathrm{rpm}$ at $35^{\circ} \mathrm{C}$ for $10 \mathrm{~min}$. The supernatant went through the membrane filter (a 0.45 $\mu \mathrm{m}$ PVDF filter, Gelman Lab, USA), which was used for lactose analysis. Sugar standard solution (Sigma, USA) is prepared to be $0.1-0.5 \%(\mathrm{w} / \mathrm{w})$, which was adjusted to $100 \mathrm{~mL}$ of final volume by adding acetonitrile.

\section{Ash content}

Five gram of milk sample was incinerated at $550^{\circ} \mathrm{C}$ and the ash content was calculated according to the AOAC method (1995).

\section{Rennet coagulation test}

The method described by McMahon et al. (1984) was slightly modified for rennet coagulation test. Briefly, each of $5 \mathrm{~mL}$ milk sample was poured into the plastic test tube, added the rennet enzyme (Christian Hansen, Denmark) up to $5 \%(\mathrm{v} / \mathrm{v})$ of the final concentration and incubated at $35^{\circ} \mathrm{C}$. After 30,60 , and $90 \mathrm{~min}$, it was tilted at a fixed angle on the flat surface and took photos of apparent viscosity of the clotted milk in the test tube.

\section{Measurements of sulfhydryl group (SH)}

Sulfhydryl groups in the milk proteins were measured by a modification method reported previously (Torovazquez and Regenstein, 1989). $0.05 \mathrm{~mL}$ of the skimmed milk was dissolved in $2 \mathrm{~mL}$ of Tris-glycine buffer solution (dissolved $20 \mathrm{~g}$ Tris, $13.5 \mathrm{~g}$ glycine, and $6 \mathrm{~g}$ EDTA into $1 \mathrm{~L}$ distilled water and adjusted to $\mathrm{pH} 8.0$ ) and $2.5 \mathrm{~mL}$ of $5 \mathrm{M}$ guanidine hydrochloride, adjusted the final volume to 5 $\mathrm{mL}$ with distilled water.

\section{Analysis of soluble calcium}

An Inductively Coupled Plasma analysis system (Optima 3300XL, Perkin Elmer, USA) was utilized for quantitation. The pre-treatment was conducted according to the official AOAC method (1995). About $2 \mathrm{~g}$ of sample was taken into the melting vessel, incinerated in the electric furnace at about $550^{\circ} \mathrm{C}$, diluted at the appropriate level with distilled water and the diluted solution of $\mathrm{HCl}$, which was
Table 3. Optimum operational conditions for determination of calcium by ICP

\begin{tabular}{lc}
\hline \hline \multicolumn{1}{c}{ Items } & Conditions \\
\hline Wave length & $317.93 \mathrm{~nm}$ \\
Nebulisation pressure & $1.0 \mathrm{bar}$ \\
Entrance slit & 20 \\
Exit slit & 80 \\
Increment & $0.004 \mathrm{~nm}$ \\
Generator power & $1,000 \mathrm{~W}$ \\
\hline sample gas flow rate & $0.7 \mathrm{~L} / \mathrm{min}$ \\
Plasma gas flow rate & $12 \mathrm{~L} / \mathrm{min}$ \\
Auxilary gas flow rate & $0 \mathrm{~L} \mathrm{~min}$ \\
Nebulisation flow rate & $0.02 \mathrm{~L} / \mathrm{min}$ \\
\hline
\end{tabular}

used as a sample solution. Standard solution was prepared for calcium at the concentrations of 1, 2.5, 5.0,10.0 mg/ $100 \mathrm{~mL}$ (Table 3).

\section{Statistical analysis}

Data of the experiments were statistically treated with the use of Statistic Analysis System (SAS Ver. 9.2 Program) and verified with Duncan's multiple range test $(p<0.05)$.

\section{Results and Discussion}

\section{General ingredients}

Table 4 shows the analysis data of general ingredients after removing fat from the milk samples. Protein concentration was ranged 2.98 to $3.03 \%$, fat 0.99 to $1.05 \%$, lactose 4.69 to $4.78 \%$ and ash 0.62 to $0.66 \%$. Judging from the data of little differences between the measured values for each ingredient, it appears that the heating time and temperature to the milk do not affect the content of respective general ingredients. After ultrafiltration of the skimmed milk samples above, the results of general ingredients in the samples prepared by using the high molecular membrane (Mw cut-off $30 \mathrm{kD}$ ) and the low molecular membrane (Mw cut-off $10 \mathrm{kD}$ ) as shown in Table 5 and 6. Protein levels of the permeates passed through the primary ultrafiltration was 0.49 to $0.57 \%$ and fat 0.45 to $0.52 \%$, showing a greater reduction in both ingredients than those of non-ultrafiltrated samples. The contents of lactose and ash, on the other hand, showed no major changes as expected. The permeates through the secondary ultrafiltration were 0.28 to $0.33 \%$ for protein and 0.17 to $0.22 \%$ for fat, which substantially decreased compared to those in the permeates through the primary ultrafiltration only, but the contents of lactose and ash had no major change, as expected. High molecular weight components fail to penetrate the membrane in the process of ultrafiltration, measured at a very low level in the permeates, whereas low- 
Table 4. General compositions of raw milk and some commercial milk products

\begin{tabular}{cccccc}
\hline \hline \multirow{2}{*}{ Method } & \multirow{2}{*}{ Symbol* } & \multicolumn{2}{c}{ Amount (\%) } \\
\cline { 3 - 6 } & & Protein & Fat & Lactose & Ash \\
\hline Raw milk & $\mathrm{R}$ & $3.01 \pm 0.03^{\mathrm{a}}$ & $0.99 \pm 0.01^{\mathrm{d}}$ & $4.71 \pm 0.06^{\mathrm{a}}$ & $0.66 \pm 0.01^{\mathrm{a}}$ \\
\hline \multirow{2}{*}{ Low temperature long time } & $\mathrm{A}$ & $3.02 \pm 0.02^{\mathrm{a}}$ & $1.01 \pm 0.01^{\mathrm{bcd}}$ & $4.77 \pm 0.05^{\mathrm{a}}$ & $0.62 \pm 0.0^{\mathrm{c}}$ \\
(LTLT) & $\mathrm{B}$ & $3.03 \pm 0.04^{\mathrm{a}}$ & $0.99 \pm 0.01^{\mathrm{d}}$ & $4.77 \pm 0.06^{\mathrm{a}}$ & $0.63 \pm 0.02^{\mathrm{bc}}$ \\
\hline Hight temperature short time & $\mathrm{C}$ & $3.03 \pm 0.04^{\mathrm{a}}$ & $1.00 \pm 0.01^{\mathrm{bcd}}$ & $4.69 \pm 0.03^{\mathrm{a}}$ & $0.64 \pm 0.02^{\mathrm{bc}}$ \\
\hline (HTST) & $\mathrm{D}$ & $3.03 \pm 0.06^{\mathrm{a}}$ & $0.99 \pm 0.01^{\mathrm{d}}$ & $4.76 \pm 0.04^{\mathrm{a}}$ & $0.66 \pm 0.01^{\mathrm{a}}$ \\
Ultra high temperature & $\mathrm{E}$ & $3.01 \pm 0.06^{\mathrm{a}}$ & $1.02 \pm 0.01^{\mathrm{bc}}$ & $4.78 \pm 0.05^{\mathrm{a}}$ & $0.62 \pm 0.02^{\mathrm{c}}$ \\
(UHT) & $\mathrm{G}$ & $2.99 \pm 0.04^{\mathrm{a}}$ & $1.03 \pm 0.02^{\mathrm{ba}}$ & $4.69 \pm 0.04^{\mathrm{a}}$ & $0.63 \pm 0.0^{\mathrm{bc}}$ \\
& $\mathrm{H}$ & $3.02 \pm 0.02^{\mathrm{a}}$ & $1.02 \pm 0.02^{\mathrm{bc}}$ & $4.69 \pm 0.03^{\mathrm{a}}$ & $0.62 \pm 0.02^{\mathrm{a}}$ \\
& $2.98 \pm 0.09^{\mathrm{a}}$ & $1.05 \pm 0.02^{\mathrm{a}}$ & $4.75 \pm 0.04^{\mathrm{a}}$ & $0.65 \pm 0.02^{\mathrm{a}}$ \\
\hline
\end{tabular}

*R: Raw milk, A: Ildongfoodis, B: Konkuk, C: Pasteur, D: Sangha, E: Denmark, F: Seoul , G: Maeil, H: Namyang

${ }^{\mathrm{a} \sim \mathrm{e}}$ Means with the different letter in same column are significantly different by Duncan's multiple range test $(p<0.05)$.

Table 5. General compositions of permeates obtained by ultrafiltration(Mw cut-off $30 \mathrm{kD}$ membrane)

\begin{tabular}{cccccc}
\hline \hline \multirow{2}{*}{ Methods } & \multirow{2}{*}{ Symbol* $^{*}$} & \multicolumn{3}{c}{ Content (\%) } \\
\cline { 3 - 6 } & & Protein & Fat & Lactose & Ash \\
\hline Raw milk & $\mathrm{R}$ & $0.57 \pm 0.01^{\mathrm{a}}$ & $0.47 \pm 0.01^{\mathrm{d}}$ & $4.68 \pm 0.07^{\mathrm{a}}$ & $0.65 \pm 0.02^{\mathrm{a}}$ \\
\hline \multirow{2}{*}{ Low temperature long time } & $\mathrm{A}$ & $0.50 \pm 0.00^{\mathrm{b}}$ & $0.51 \pm 0.01^{\mathrm{a}}$ & $4.65 \pm 0.06^{\mathrm{a}}$ & $0.61 \pm 0.01^{\mathrm{b}}$ \\
(LTLT) & $\mathrm{B}$ & $0.49 \pm 0.01^{\mathrm{b}}$ & $0.52 \pm 0.02^{\mathrm{a}}$ & $4.59 \pm 0.11^{\mathrm{a}}$ & $0.60 \pm 0.01^{\mathrm{b}}$ \\
& $\mathrm{C}$ & $0.56 \pm 0.02^{\mathrm{a}}$ & $0.48 \pm 0.0^{\mathrm{dc}}$ & $4.59 \pm 0.11^{\mathrm{a}}$ & $0.62 \pm 0.0^{\mathrm{ba}}$ \\
\hline Hight temperature short time & $\mathrm{D}$ & $0.49 \pm 0.02^{\mathrm{b}}$ & $0.47 \pm 0.0^{\mathrm{d}}$ & $4.59 \pm 0.08^{\mathrm{a}}$ & $0.65 \pm 0.02^{\mathrm{a}}$ \\
(HTST) & $\mathrm{E}$ & $0.50 \pm 0.01^{\mathrm{b}}$ & $0.45 \pm 0.02^{\mathrm{e}}$ & $4.61 \pm 0.02^{\mathrm{a}}$ & $0.62 \pm 0.02^{\mathrm{ba}}$ \\
\hline \multirow{2}{*}{ Ultra high temperature } & $\mathrm{F}$ & $0.49 \pm 0.02^{\mathrm{b}}$ & $0.49 \pm 0.0^{\mathrm{bc}}$ & $4.65 \pm 0.05^{\mathrm{a}}$ & $0.62 \pm 0.0^{\mathrm{ba}}$ \\
(UHT) & $\mathrm{G}$ & $0.56 \pm 0.01^{\mathrm{a}}$ & $0.51 \pm 0.01^{\mathrm{a}}$ & $4.66 \pm 0.10^{\mathrm{a}}$ & $0.62 \pm 0.02^{\mathrm{ba}}$ \\
& $\mathrm{H}$ & $0.57 \pm 0.02^{\mathrm{a}}$ & $0.52 \pm 0.0^{\mathrm{a}}$ & $4.65 \pm 0.07^{\mathrm{a}}$ & $0.62 \pm 0.02^{\mathrm{ba}}$ \\
\hline
\end{tabular}

*R: Raw milk, A: Ildongfoodis, B: Konkuk, C: Pasteur, D: Sangha, E: Denmark, F: Seoul, G: Maeil, H: Namyang

${ }^{\mathrm{a} \sim \mathrm{e}}$ Means with the different letter in same column are significantly different by Duncan's multiple range test $(p<0.05)$.

Table 6. General compositions of permeate obtained by ultrafiltration (Mw cut-off $10 \mathrm{kD}$ membrane)

\begin{tabular}{cccccc}
\hline \hline \multirow{2}{*}{ Methods } & \multirow{2}{*}{ Symbol* $^{*}$} & \multicolumn{3}{c}{ Content (\%) } \\
\cline { 3 - 6 } & & Protein & Fat & Lactose & Ash \\
\hline Raw milk & $\mathrm{R}$ & $0.32 \pm 0.0^{\mathrm{a}}$ & $0.22 \pm 0.0^{\mathrm{a}}$ & $4.45 \pm 0.07^{\mathrm{a}}$ & $0.64 \pm 0.0^{\mathrm{a}}$ \\
\hline \multirow{2}{*}{ Low temperature long time } & $\mathrm{A}$ & $0.33 \pm 0.01^{\mathrm{a}}$ & $0.21 \pm 0.01^{\mathrm{ba}}$ & $4.49 \pm 0.05^{\mathrm{a}}$ & $0.61 \pm 0.0^{\mathrm{ba}}$ \\
(LTLT) & $\mathrm{B}$ & $0.28 \pm 0.01^{\mathrm{c}}$ & $0.20 \pm 0.01^{\mathrm{bc}}$ & $4.47 \pm 0.07^{\mathrm{a}}$ & $0.60 \pm 0.0^{\mathrm{b}}$ \\
\hline Hight temperature short time & $\mathrm{C}$ & $0.28 \pm 0.0^{\mathrm{c}}$ & $0.19 \pm 0.0^{\mathrm{dc}}$ & $4.49 \pm 0.05^{\mathrm{a}}$ & $0.62 \pm 0.0^{\mathrm{ba}}$ \\
\hline (HTST) & $\mathrm{D}$ & $0.29 \pm 0.0^{\mathrm{bc}}$ & $0.18 \pm 0.0^{\mathrm{de}}$ & $4.46 \pm 0.05^{\mathrm{a}}$ & $0.63 \pm 0.0^{\mathrm{ba}}$ \\
Ultra high temperature & $\mathrm{E}$ & $0.28 \pm 0.01^{\mathrm{c}}$ & $0.17 \pm 0.01^{\mathrm{e}}$ & $4.47 \pm 0.07^{\mathrm{a}}$ & $0.62 \pm 0.0^{\mathrm{ba}}$ \\
(UHT) & $\mathrm{G}$ & $0.31 \pm 0.0^{\mathrm{ba}}$ & $0.20 \pm 0.0^{\mathrm{c}}$ & $4.49 \pm 0.08^{\mathrm{a}}$ & $0.61 \pm 0.0^{\mathrm{ba}}$ \\
& $\mathrm{H}$ & $0.31 \pm 0.0^{\mathrm{ba}}$ & $0.21 \pm 0.01^{\mathrm{ba}}$ & $4.45 \pm 0.02^{\mathrm{a}}$ & $0.62 \pm 0.0^{\mathrm{ba}}$ \\
& $0.32 \pm 0.01^{\mathrm{a}}$ & $0.20 \pm 0.01^{\mathrm{bc}}$ & $4.49 \pm 0.02^{\mathrm{a}}$ & $0.61 \pm 0.0^{\mathrm{ba}}$ \\
\hline
\end{tabular}

*R: Raw milk, A: Ildongfoodis, B: Konkuk, C: Pasteur, D: Sangha, E: Denmark, F: Seoul, G: Maeil, H: Namyang

${ }^{\mathrm{a} \sim \mathrm{e}}$ Means with the different letter in same column are significantly different by Duncan's multiple range test $(p<0.05)$.

molecular weight lactose goes easily through the membrane, resulted in the similar content each other. After ultrafiltration, the contents of fat, protein and non-fat milk solids of the permeates were in the very low level, whereas lactose was the similar results to the previous report by Chon et al. (2012) that lactose drew no big difference in the contents between raw milk, concentrated milk, and UF-permeate. Based on the results that there was a greater reduction in content of protein in the ultra- filtered milk than that of general skim milk, colloidal calcium were thought to be almost removed.

\section{pH Measurement}

Table 7 indicates the $\mathrm{pH}$ values of the skim milk differently heat-treated and their permeates through primary ultrafiltration membrane (Mw cut-off $30 \mathrm{kD}$ ) and secondary ultrafiltration membrane (Mw cut-off $10 \mathrm{kD}$ ). The raw milk prior to ultrafiltration and the $\mathrm{pH}$ value of pasteur- 
Table 7. pH values in raw milk and some commercial milk products

\begin{tabular}{|c|c|c|c|c|}
\hline \multirow{2}{*}{ Methods } & \multirow{2}{*}{ Symbol* } & \multicolumn{3}{|c|}{$\overline{\mathrm{pH}}$} \\
\hline & & Skimmed milk & Ultrafiltration $(30 \mathrm{kD})$ & Ultrafiltration $(10 \mathrm{kD})$ \\
\hline Raw milk & $\mathrm{R}$ & $6.62 \pm 0.01^{\mathrm{a}}$ & $6.69 \pm 0.01^{\mathrm{a}}$ & $6.69 \pm 0.02^{\mathrm{a}}$ \\
\hline \multirow{3}{*}{$\begin{array}{l}\text { Low temperature long time } \\
\text { (LTLT) }\end{array}$} & A & $6.62 \pm 0.02^{\mathrm{a}}$ & $6.67 \pm 0.01^{b}$ & $6.67 \pm 0.0^{\mathrm{bc}}$ \\
\hline & B & $6.62 \pm 0.0^{\mathrm{a}}$ & $6.67 \pm 0.01^{\mathrm{b}}$ & $6.68 \pm 0.0^{\mathrm{ba}}$ \\
\hline & $\mathrm{C}$ & $6.62 \pm 0.0^{\mathrm{a}}$ & $6.66 \pm 0.01^{\mathrm{cb}}$ & $6.66 \pm 0.0^{\mathrm{bc}}$ \\
\hline \multirow{2}{*}{$\begin{array}{l}\text { Hight temperature short time } \\
\text { (HTST) }\end{array}$} & $\mathrm{D}$ & $6.62 \pm 0.0^{\mathrm{a}}$ & $6.69 \pm 0.01^{\mathrm{a}}$ & $6.69 \pm 0.02^{\mathrm{a}}$ \\
\hline & E & $6.62 \pm 0.01^{\mathrm{a}}$ & $6.67 \pm 0.01^{\mathrm{b}}$ & $6.67 \pm 0.0^{\mathrm{bc}}$ \\
\hline \multirow{3}{*}{$\begin{array}{l}\text { Ultra high temperature } \\
\text { (UHT) }\end{array}$} & $\mathrm{F}$ & $6.57 \pm 0.01^{\mathrm{c}}$ & $6.64 \pm 0.01^{\mathrm{d}}$ & $6.65 \pm 0.02^{\mathrm{c}}$ \\
\hline & G & $6.58 \pm 0.0^{\mathrm{cb}}$ & $6.65 \pm 0.01^{\mathrm{cd}}$ & $6.65 \pm 0.01^{\mathrm{c}}$ \\
\hline & $\mathrm{H}$ & $6.59 \pm 0.0^{\mathrm{b}}$ & $6.65 \pm 0.01^{\mathrm{cd}}$ & $6.66 \pm 0.0^{\mathrm{bc}}$ \\
\hline
\end{tabular}

*R: Raw milk, A: Ildongfoodis, B: Konkuk, C: Pasteur, D: Sangha, E: Denmark, F: Seoul, G: Maeil, H: Namyang

${ }^{\mathrm{a} \sim \mathrm{e}}$ Means with the different letter in same column are significantly different by Duncan's multiple range test $(p<0.05)$.

ized milk products (HTST- and LTLT-milk) was 6.62, showing no difference in $\mathrm{pH}$ values. The UHT milk, however, was 6.57 to 6.59 of a relatively lower $\mathrm{pH}$. The $\mathrm{pH}$ of all treatments through primary and secondary ultrafiltration returned 6.64 to 6.69 , resulted in slightly higher $\mathrm{pH}$ than non-ultrafiltrated samples. The reason that the $\mathrm{pH}$ slightly increased following the ultrafiltration is explained mainly due to the fact that part of minerals slipped out into the permeate. This result is similar to the one form the previous study (On-Nom et al., 2010) that $\mathrm{pH}$ value slightly goes up when milk is ultrafiltrated.

\section{Rennet coagulation test}

Fig. 1 shows the results of milk coagulation experiment after adding rennet to each sample and incubated for 30 , $60,90 \mathrm{~min}$, respectively. After every $30 \mathrm{~min}$ following addition of rennet, milk coagulation was measured, resulted that raw milk was confirmed to have the most effective compared to other samples, and additional incubation of 90 min has little change on the apparent coagulation state of HTST- and UHT-treated milk used. The UHT-treat milk,

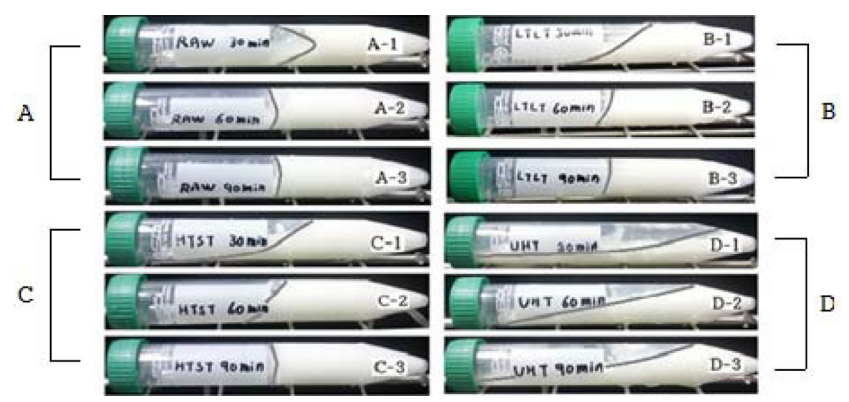

Fig. 1. Results of the rennet coagulation test on raw milk and some commercial milk products after incubation for 30(1), 60(2), and 90(3) min, respectively. A1-A3: Raw milk, B1-B3: LTLT (Low temperature long time) treated milk, C1-C3: HTST (Hight temperature short time) treated milk, D1-D3: UHT (Ultra high temperature) treated milk. on the other hand, was considerably reduced in coagulation activity, compared to other samples where the coagulation state of the UHT-treated milk after 90 min incubation significantly dropped in rennet coagulation activity than those of raw milk, HTST-, and LTLT-treated milk. These results hold a similar tendency to other's work (Ham et al., 2008) that coagulation activity of raw milk was the most effective at 60 min after adding rennet to the UHTtreated milk and raw milk was far more effective than UHT-treated milk in terms of milk coagulation.

As for the mechanism addressing milk coagulation, phenylalanine (105)-methionine (106) of $\kappa$-casein is sensitive to proteolytic enzyme rennet. Accordingly, stability of casein micelle decreases and gets coagulated when this peptide bond is digested. If heated at high temperature, however, the sensitivity of $\kappa$-casein to rennet reduce in coagulation strength because enzyme action is hindered as a result of the complex between $\beta$-lactoglobulin and $\kappa$ casein (Lucey, 1995). Sterilization process of raw milk is known to have a critical effect on the balance of calcium phosphate and the balance of colloidal calcium phosphate-k-casein complex. When the ratio between soluble calcium and colloidal calcium increases, clotting time by rennet extends. Therefore, when soluble calcium is added, it was suggested that the clotting time of milk can be shortened by complementing the amount of calcium ion lost by heat treatment (Kim et al., 2011).

\section{Measurement of sulfhydryl group}

The sulfhydryl group in intact milk proteins becomes activated and concomitant changes of its tertiary structure during heat treatment. When heat is applied to milk, volatile sulfide compounds are formed to generate the cooked flavor as a off-flavor as some sulfur-containing amino acids liberate the sulfhydry groups (Jaddou and Pavey, 1978). When milk proteins are contacted to heat, it tends to cause 
Table 8. Contents of the sulfhydryl group of raw milk and some commercial milk products

\begin{tabular}{ccc}
\hline \hline Methods & Symbol* & $\begin{array}{c}\text { Sulfhydryl group } \\
(\mu \mathrm{M} / \mathrm{g} \text { protein })\end{array}$ \\
\hline Raw milk & $\mathrm{R}$ & $2.71 \pm 0.09^{\mathrm{c}}$ \\
\hline Low temperature & $\mathrm{A}$ & $3.22 \pm 0.10^{\mathrm{ba}}$ \\
long time (LTLT) & $\mathrm{B}$ & $3.30 \pm 0.08^{\mathrm{ba}}$ \\
& $\mathrm{C}$ & $3.23 \pm 0.05^{\mathrm{ba}}$ \\
\hline Hight temperature & $\mathrm{D}$ & $3.33 \pm 0.09^{\mathrm{ba}}$ \\
short time (HTST) & $\mathrm{E}$ & $3.39 \pm 0.11^{\mathrm{a}}$ \\
\hline Ultra high temperature & $\mathrm{F}$ & $3.38 \pm 0.14^{\mathrm{a}}$ \\
(UHT) & $\mathrm{G}$ & $3.35 \pm 0.09^{\mathrm{a}}$ \\
& $\mathrm{H}$ & $3.29 \pm 0.13^{\mathrm{ba}}$ \\
\hline
\end{tabular}

*R: Raw milk, A: Ildongfoodis, B: Konkuk, C: Pasteur, D: Sangha, E: Denmark,F: Seoul, G: Maeil, H: Namyang

${ }^{\mathrm{a} \sim \mathrm{e}}$ Means with the different letter in same column are significantly different by Duncan's multiple range test $(p<0.05)$.

a structural change, exposed the inside $\mathrm{SH}$ groups to the outside, therefore the amounts of SH group is consequently influenced by the time and the temperature applied, composition of raw milk, initial acidity, oxygen content, and storage conditions (Klostermeyer, 1976). As shown in Table 8, the values for SH groups in the commercial milk products (symbol A to $\mathrm{H}$ ) were measured to be 3.22-3.39, while the value of raw milk was 2.71 , which is significantly lower than in the heat-treated samples. This result indicates the structural change in milk proteins probably took place even by means of pasteurization or sterilization process. To confirm the structural changes in casein according to heat treatment, non-denaturation polyacrylamide gel electrophorosis (ND-PAGE) was performed. However, the banding pattern was all identical to those of the denatured samples on polyacrylamide gel electrophoresis (Fig. 2).

\section{Determination of total calcium and soluble calcium}

As shown in Table 9, content of the total calcium in the

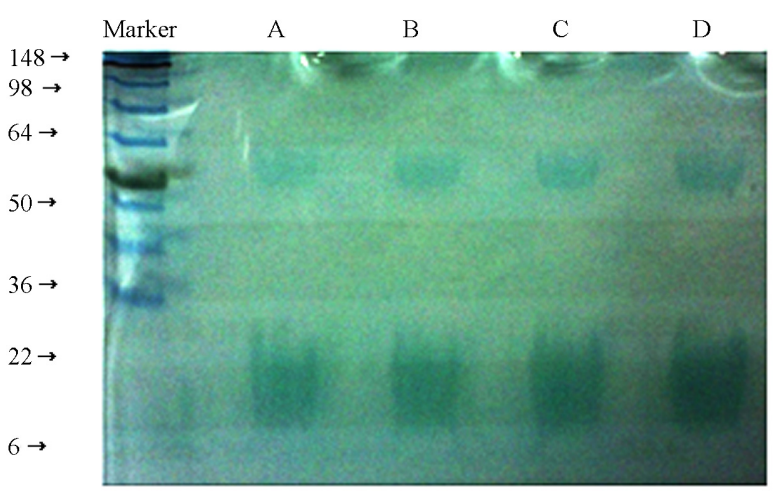

Fig. 2. Non-denaturation polyacrylamide gel electrophorosis (ND-PAGE) of defatted raw milk and some commercial milk products defatted. A: Raw milk, B: LTLT (Low temperature long time) treated milk, C: HTST (Hight temperature short time) treated milk, D: UHT (Ultra high temperature) treated milk.

market milk products and raw milk. have shown that the raw milk contained the highest value of $1,111 \mathrm{mg} / \mathrm{kg}$, and product $\mathrm{H}$ (UHT- treated) was the lowest value of 1,056 $\mathrm{mg} / \mathrm{kg}$. No significant difference $(p<0.05)$ was found in each sample as for the total calcium content. A similar tendency was found in the earlier report, claimed that heat treatment has no influence on the total calcium content in milk (Sandhu, 1973). For determination of soluble calcium, ultrafiltration was conducted with the primary (Mw cut-off $30 \mathrm{Kd}$ ) and the secondary membrane (Mw cut-off $10 \mathrm{kD}$ ) in order were carried out, resulted that the total calcium content was between 27.4 and $41 \%$. This result was very similar to the values previously reported by Miguel et al. (2004) that the soluble calcium of UHT milk accounts for 24 to $37 \%$ of the total calcium content. Total calcium contents in the market milk products were as follows: UHT-milk was 370.3 to $380.2 \mathrm{mg} / \mathrm{kg}$; LTLTmilk, 336.4 to $345.1 \mathrm{mg} / \mathrm{kg}$; HTST-milk, 305.5 to 313.3 $\mathrm{mg} / \mathrm{kg}$. After secondary ultrafiltration, total calcium in raw

Table 9. Concentrations of total and soluble calcium in raw milk and some commercial milk products

\begin{tabular}{|c|c|c|c|c|}
\hline \multirow{2}{*}{ Methods } & \multirow{2}{*}{ Symbol* } & \multirow{2}{*}{ Total calcium $(\mathrm{mg} / \mathrm{mL})$} & \multicolumn{2}{|c|}{ Soluble calcium $(\mathrm{mg} / \mathrm{mL})$} \\
\hline & & & by UF membrane $(30 \mathrm{kD})$ & by UF membrane $(10 \mathrm{kD})$ \\
\hline Raw milk & $\mathrm{R}$ & $1111.3 \pm 21.3^{\mathrm{a}}$ & $450.2 \pm 3.5^{\mathrm{a}}$ & $442.2 \pm 6.7^{\mathrm{a}}$ \\
\hline \multirow{3}{*}{$\begin{array}{l}\text { Low temperature long time } \\
\text { (LTLT) }\end{array}$} & A & $1087.2 \pm 17.8^{\mathrm{a}}$ & $336.4 \pm 2.4^{\mathrm{e}}$ & $333.3 \pm 7.8^{\mathrm{c}}$ \\
\hline & B & $1091.1 \pm 21.9^{\mathrm{a}}$ & $337.2 \pm 3.4^{\mathrm{ed}}$ & $334.1 \pm 8.2^{\mathrm{c}}$ \\
\hline & $\mathrm{C}$ & $1099.5 \pm 8.2^{\mathrm{a}}$ & $345.1 \pm 4.0^{\mathrm{d}}$ & $342.2 \pm 4.9^{\mathrm{c}}$ \\
\hline \multirow{2}{*}{$\begin{array}{l}\text { Hight temperature short time } \\
\text { (HTST) }\end{array}$} & $\mathrm{D}$ & $1100.4 \pm 40.8^{\mathrm{a}}$ & $305.5 \pm 1.8^{\mathrm{f}}$ & $301.9 \pm 7.2^{\mathrm{d}}$ \\
\hline & E & $1101.2 \pm 31.3^{\mathrm{a}}$ & $313.3 \pm 6.5^{\mathrm{f}}$ & $311.2 \pm 4.9^{\mathrm{d}}$ \\
\hline \multirow{3}{*}{$\begin{array}{l}\text { Ultra high temperature } \\
\text { (UHT) }\end{array}$} & $\mathrm{F}$ & $1086.4 \pm 8.2^{\mathrm{a}}$ & $375.4 \pm 4.1^{\mathrm{cb}}$ & $372.7 \pm 5.8^{b}$ \\
\hline & G & $1104.3 \pm 40.8^{\mathrm{a}}$ & $370.3 \pm 4.7^{\mathrm{c}}$ & $371.3 \pm 3.9^{\mathrm{b}}$ \\
\hline & $\mathrm{H}$ & $1056.5 \pm 24.5^{\mathrm{a}}$ & $380.2 \pm 4.1^{\mathrm{b}}$ & $378.2 \pm 1.6^{\mathrm{b}}$ \\
\hline
\end{tabular}

*R: Raw milk, A: Ildongfoodis, B: Konkuk, C: Pasteur, D: Sangha, E: Denmark, F: Seoul, G: Maeil, H: Namyang

${ }^{\mathrm{a} \sim \mathrm{e}}$ Means with the different letter in same column are significantly different by Duncan's multiple range test $(p<0.05)$. 
milk had a highest of $444.2 \mathrm{mg} / \mathrm{kg}$, and those in the market milk products: UHT- milk, 371.3 to $378.2 \mathrm{mg} / \mathrm{kg}$; LTLTmilk, 333.3 to $342.2 \mathrm{mg} / \mathrm{kg}$; HTST-milk 301.9 to 311.2 $\mathrm{mg} / \mathrm{kg}$ in a decreasing order. It appears that the content of soluble calcium is high as UHT-milk is contacted with heat in a short period of time (2-3 s) though the high temperature above $130^{\circ} \mathrm{C}$ was applied for sterilization. While LTLT-, HTST-milk products went through a longer time in heat treatment stage yet at a low temperature than that of UHT- milk, which might be responsible to a comparatively low content of soluble calcium.

According to the study by On-Nom et al. (2010), the content of ionic calcium as a part of the soluble calcium decreases as the heat-treatment temperature rises. A similar tendency was drawn to a previous study reported that the ionic calcium content was higher in the milk sterilized for $2 \mathrm{~s}$ at $120^{\circ} \mathrm{C}$ than in the one heat-treated for $15 \mathrm{~s}$ at $85^{\circ} \mathrm{C}$. It is said that the amount of calcium is cut down during the course of heating, sterilizing and treating milk, and that ultrafiltrable calcium content is reduced after milk is combined with the phosphoric acid or the denatured proteins, and then transferred to casein micelle and in turn to the colloidal calcium. As seen above, temperature and time for heat treatment turned out to have no particular influence on the total calcium content of milk, whereas the content of soluble calcium was confirmed to turn into colloidal calcium according to the temperature and time by heat treatment before being reduced. According to a publication (In and Jung, 2001), the decrease in the amount of soluble calcium by such a heat treatment of milk or change in its form of existence is reported to have a small impact on the bioavailability but there is still huge uncertainty. A further study needs in the future on the bioavailability of the insoluble calcium and soluble calcium.

\section{References}

1. AOAC. (1995) Official Methods of Analysis (13th ed.) Gaithersburg, MD: Association of Official Analytical Chemists.

2. Burton, H. (1984) Reviews of progress of dairy science, The bacteriological, chemical, biochemical and physical changes that occur in milk at temperatures of 100-150. J. Dairy Res. 51, 341-363.

3. Chai, B. S. (1988) Human nutritional science. Academy book, Seoul, Korea. pp.140-141.

4. Chon, J. W., Park, J. H., Lee, J. I., Song, K. Y., Kim, D. H., Kim, H. S., Hyeon, J. Y., and Seo, K. H. (2012) General composition of Mozzarella cheese made from concentrated milk derived by ultrafiltration. J. Korean Dairy Sci. Technol. 31, 907-913.
5. Ham, J. S., Shin, J. H., Noh, Y. B., Jeong, S. G., Han, G. S., Chae, H. S., Yoo, Y. M., Ahn, J. N., Lee, W. K., and Jo, C. (2008) Chemical and microbiological quality, capillary electrophoresis pattern, and rennet coagulation of UHT-treated and irradiated milk. Food Sci. Biotechnol. 17, 58-65.

6. Holt, C. and Jenness, R. (1984) Interrelationships of constituents and partition of salts in milk samples from eight species. Comp. Biochem. Physiol. 77, 275-282.

7. In, Y. M. and Jung, J. K. (2001) Review on the change of physicochemical quality during heating of milk. J. Kor. Dairy Sci. Technol. 19, 13-21.

8. Jaddou, H. A. and Pavey, D. J. (1978) Manning. Chemical analysis of flavor vilatiles in heat treated milks. J. Dairy Res. 45, 391-403.

9. Kim, G. Y., Kim, W. S., Kim, C. H., Nam, M. S., Oh, S. J., Moon, Y. I., Yoon, S. S., Lee, S. W., Lee, W. J., Jeon, W. M., and Ha, W. K. (2011) Milk Processing Technology. Yuhansa, Seoul, Korea. pp. 222-223.

10. Kim, S. H. (1993) Ca nutrition and osteoporosis in Korea. Kor. J. Nutr. 26, 203-212.

11. Klostermeyer, H. (1976) Veraenerungen des milcheiweisses beim erhitzen. Molk, Zeit. Welt Milch. 30, 818-823.

12. Lee, J. W., Hwang, Y. S., Hong, S. N., and Im, H. S. (1993) Effects of dietary calcium levels on blood pressure and calcium metabolism in normotensive female young adults with the hypertension family history. Kor. J. Nutr. 26, 728-742.

13. Lee, S. J. (1999) Effects of milks by various heat treatment. J. Seokang College 10, 311-320.

14. Lee, Y. S. and Kim, E. M. (2002) Effect of dietary Ca and $\mathrm{Na}$ levels on blood pressure and mineral metabolism in spontaneously hypertensive rats fed high fat diet. Kor. J. Nutr. 35, 840-847.

15. Lucey, J. A. (1995) Effect of heat treatment on the rennet coagulability of milk. In: Heat-induced changes in milk. Fox PF (ed). IDF Special Issue 9501, International Dairy Federation, Brussels, Belgium. pp. 171-187.

16. McMahon, D. J., Brown, R. J., Richardson, G. H., and Ernstrom, C. A. (1984) Effects of calcium phosphate, and bulk culture media on milk coagulation properties. J. Dairy Sci. 67, 930-938.

17. Miguel, A., Josefina, B., and Manuela, J. (2004) Mineral contents and distribution between the soluble and the micellar phases in calcium-enriched UHT milks. J. Sci. Food Agri. 84, 1708-1714.

18. Neville, M. C., Keller, R. P., Casey, C., and Allen, J. C. (1994) Calcium partitioning in human and bovine milk. J. Dairy Sci. 77, 1964-1975.

19. On-Nom, N., Grandison, A. S., and Lewis, M. J. (2010) Measurement of ionic calcium, $\mathrm{pH}$, and soluble divalent cations in milk at high temperature. J. Dairy Sci. 93, 515-523.

20. Park, K. S. and Lee, K. A. (2002) A case study on the effect of Ca intake on depression and anxiety. Kor. J. Nutr. 35, 4552.

21. Pouliot, Y., Boulet, M., and Paquin, P. (1989) Observations on the heat induced salt balance changes in milk. J. Dairy Sci. 
56, 193-199.

22. Sandhu, M. (1973) The mineral and vitamin contents of milk as influenced by the method of processing. Parkistan. J. Food Sci. 25, 246-252.

23. Toro-Vazquez, J. F. and Regenstein, J. M. (1989) Physico- chemical parameters of protein additives and their emulsifying properties. J. Food Sci. 54, 1177-1182.

24. Woo, S. J. and Maeng, Y. S. (1998) Nutrition of Milk and Dairy Products. Hyo-Il, Seoul, Korea. pp. 161-164.

(Received 2013.2.12/Revised 2013.6.12/Accepted 2013.6.19) 